\title{
CULTIVATION AND HARDINESS NOTES FOR BLECHNUM CYCADIFOLIUM
}

\author{
Andrew Ensoll ${ }^{1}$ and Kate Hughes ${ }^{2}$
}

Blechnum cycadifolium is an evergreen fern from the Juan Fenandez islands. This paper starts by describing its collection, propagation and cultivation and then considers its hardiness. Three planting areas are described, followed by notes about how the plants overwintered in these areas.

\section{INTRODUCTION}

Blechnum cycadifolium (Blechnaceae) is an evergreen fern with foliage and a habit that resembles a cycad. It is endemic to the Juan Fernandez Islands in the Pacific Ocean.

This group of three islands, Masatierra, Masafuera and Santa Clara lie $667 \mathrm{~km}$ off the coast of Chile at 35 $50^{\prime} \mathrm{S}$ and $80^{\circ} 00^{\prime} \mathrm{W}$ (Haberle, 1999). See Ensoll and Matthews (2004) for further details on the climate and topography of the islands.

Masatierra is also known as 'Robinson Crusoe Island' because the writer Daniel Defoe was inspired by Alexander Selkirk, who spent four years in isolation on this island. Blechnum cycadifolium occurs from sea level up to the tops of the rocky mountains which characterise the island's geography. Plants can be found growing in damp gullies and on open rock faces exposed to the sea winds (Fig. 1). They are described as 'common on mountain chains at 500m' (S.Haberle 1999).

\section{Description of the plant}

The fronds which grow up to $2 \mathrm{~m}$ in length are dark to mid green, shiny and leathery, with brown coloured scales on the underside. When growing in full sun the whole frond folds up in the same way that those of the Cycad species Cycas revoluta do. It is because of this characteristic that the plant is named 'cycadifolium'. Mature specimens can form a trunk up to $2 \mathrm{~m}$ in height and very mature plants eventually become multistemmed because side shoots grow which also develop trunks. Plants are dimorphic which means that they produce distinct spore bearing fronds in addition to sterile fronds.

\footnotetext{
${ }^{1}$ Andrew Ensoll is a Senior Horiculturist at Royal Botanic Garden Edinburgh

Address: 20A, Inverleith Row, Edinburgh EH3 5LR

Email: A.Ensoll@rbge.ac.uk

${ }^{2}$ Kate Hughes is a Horticulturist at Royal Botanic Garden Edinburgh and Assistant Editor of Sibbaldia

Address: As above

Email: K.Hughes@rbge.ac.uk
} 


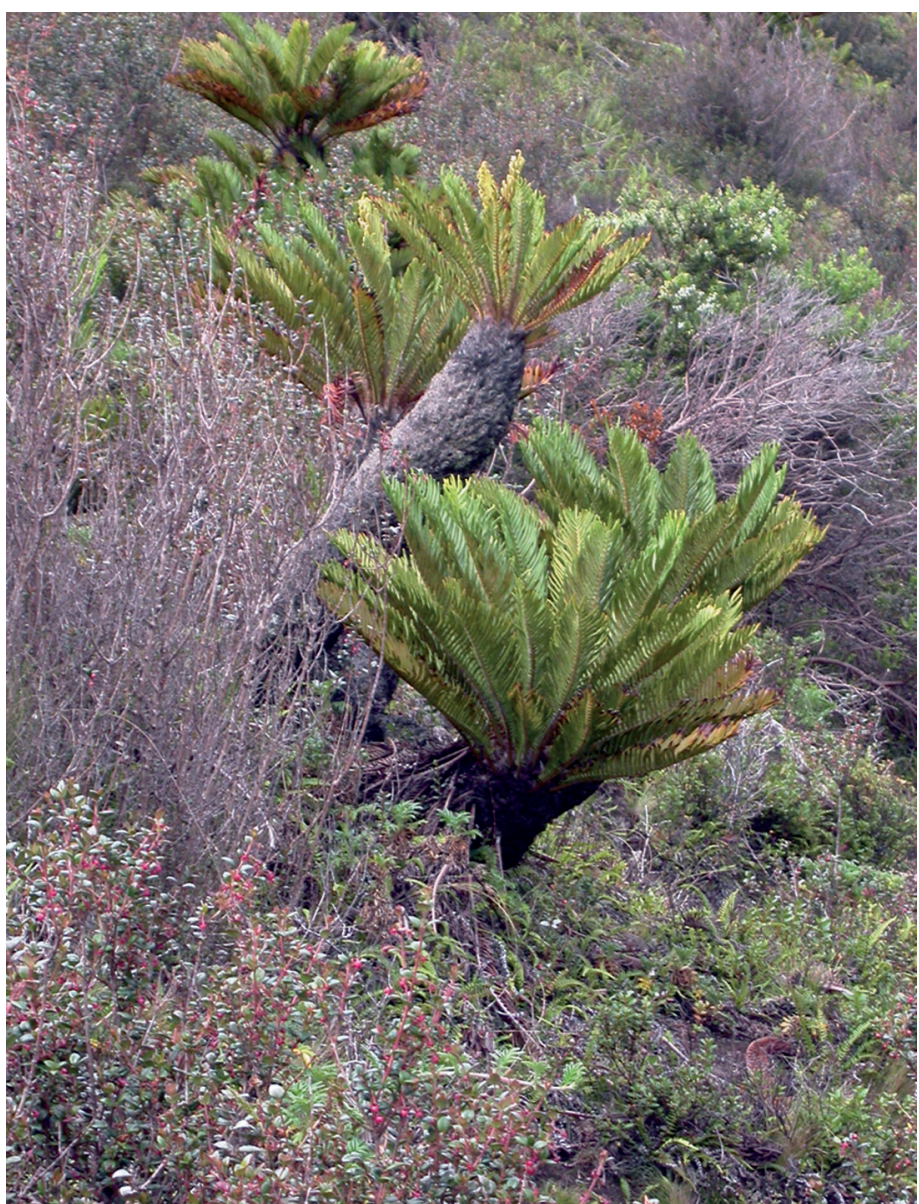

Fig. 1 Blechnum cycadifolium in its native environment on the slopes of Masatierra surrounded by mixed native and exotic invasive species. Photo: Martin Gardner.

\section{Collection, propagation and cultivation}

In 2004 spores were collected from Masatierra by Gardner and Hechenleitner. The notes for this collection were as follows:

Narrow ridge with mostly invasive non-native species including Aristotelia chilensis and Ugni molinae. Slope badly eroded. Dominant native species include: Blechnum cycadifolium and scattered shrubs of Escallonia callcottiae and Drimys confertifolia. Alt $211 \mathrm{~m}$

The spores were sown on 12 January 2004 and germinated on 24 January 2004. They were patched off/pricked out on 22 February 2004. When the sporophytes appeared they were potted up individually (see Ensoll and Matthews, 2004 for spore 
sowing techniques). In summer 2004 they were acclimatised to glasshouse conditions where they were grown in an intermediate glasshouse with a maximum day temperature of $15^{\circ} \mathrm{C}$. Air vents opened in the glasshouse when temperatures reached $18^{\circ} \mathrm{C}$ and at night the minimum temperature was set at $13^{\circ} \mathrm{C}$. The young plants were grown on in these conditions until late spring 2005 . At this time they were moved to a slightly cooler glasshouse with a maximum temperature of $13^{\circ} \mathrm{C}$ and a minimum temperature of $10^{\circ} \mathrm{C}$.

Blechnum cycadifolium plants growing in glasshouses are prone to 'crown rot', a bacterial disease caused by Pseudomonas sp. This disease thrives where there is a lack of air movement and it deforms the fronds and slows the growth rate of plants. Because of this the decision was made to grow some of the maturing plants in a number of locations outside to see how they fared in the Scottish climate.

\section{THE LOCATIONS}

- The South American area (border number T27 at Royal Botanic Garden Edinburgh Inverleith). This area was created in the garden to accommodate the extensive collection of Chilean plants at Royal Botanic Garden Edinburgh (RBGE). The beds are located between the large public glasshouses and the wall separating the public garden from the back up and research glasshouses. This area experiences warm dry conditions in summer and in winter the large glasshouses flanking the south and west of the area and the wall on the north offer slight protection from frost. However, these same glasshouses form a barrier to the low winter sun and cold air is unable to drain away. During the winter of 2005/06 minimum temperatures experienced at RBGE were $-6^{\circ} \mathrm{C}$ on December 17. It is thought that the South American area would only have reached temperatures slightly above those of the main garden. A group of 5 plants of $B$. cycadifolium were planted in a loamy soil with added propagation bark. Propagation bark is pine bark milled to approximately five millimetres

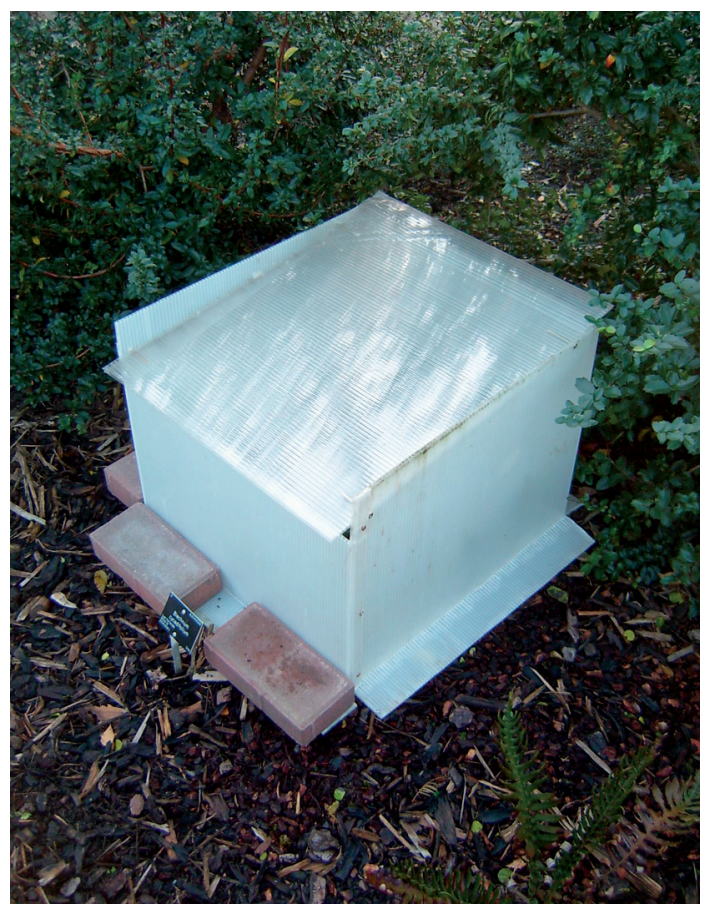

Fig. 2 Blechnum cycadifolium at RBGE Inverleith protected by a corex case in winter 2007. Photo: Sadie Barber. 
in diameter. 'Enmag' is a proprietorial very slow release fertiliser containing magnesium and nitrogen phosphates and this was added to the planting holes. The plants were top dressed with a pine bark mulch. In preparation for the winter of 2006/07 a 'corex' (twin walled polycarbonate material) case was placed around the plant which had survived the winter of 2005/06 to see whether this extra protection would enable it to come through the winter in an even better condition. (Fig. 2)

- The Courtyard at RBGE, Inverleith. The climatic conditions of this area have been noted in Wardlaw (2005) and are briefly described by Ensoll, Galloway and Wardlaw again in this issue of Sibbaldia. Although it is open to the sky, the area is extremely sheltered. The minimum air temperature in the winter of 2005/06 was $-5.2^{\circ} \mathrm{C}\left(0.8^{\circ} \mathrm{C}\right.$ warmer than the open garden $)$. The blechnum plants were planted in loamy soil with added propagation bark and 'Enmag' in September 2005.

- Logan Botanic Garden. Located in the Rhins of Galloway, south west Scotland, the garden has a mild coastal climate. A number of Blechnum cycadifolium were planted in two locations. The first was a very sheltered location (Location 1), overhung by trees, which meant that they were in semi-shade. During dry periods they were irrigated. The second location (Location 2) is sheltered on the south and east sides but is:

"exposed to winds from the west which can be rather fierce and cold. Hence in the winter we provide them with a wee bit of additional protection on placing solid plastic windbreaks around them. The area in general is on a north facing slope and the plants are pretty much at the top of it." (Colin Belton, pers. comm.)

The minimum temperature for the winter of $2005 / 06$ was $-4.2^{\circ} \mathrm{C}$ experienced in March. This was an unusually cold March but such temperatures are not unusual in January or February in this garden.

Another planting is planned in 'Location 3' which will be replacing a group of over mature escallonias. The bracken will be sprayed off and the B. cycadifolium will be planted at the foot of a slope on the Chilean area. Colin Belton, (pers. comm. 2006) supervisor at Logan describes the site as follows:

"This is north facing. Here they will be exposed to winds from the north and because there are no trees offering any protection to these they are going to be rather exposed to them. They will however have shelter from the wind on the $W, S$ and $E$ but they will not have any shade though. The soil in general is sandy loam that is neutral to slightly acidic. So when we do any planting we always incorporate a good quantity of both planting mix (composted bark and fertiliser) along with some additional Enmag."

Our windiest times tend to come in the autumn-winter period on the whole, predominantly from the south west, 50+mph, which can be laden with salt being only about a 1.1 miles away, as the crow flies, from the sea. 


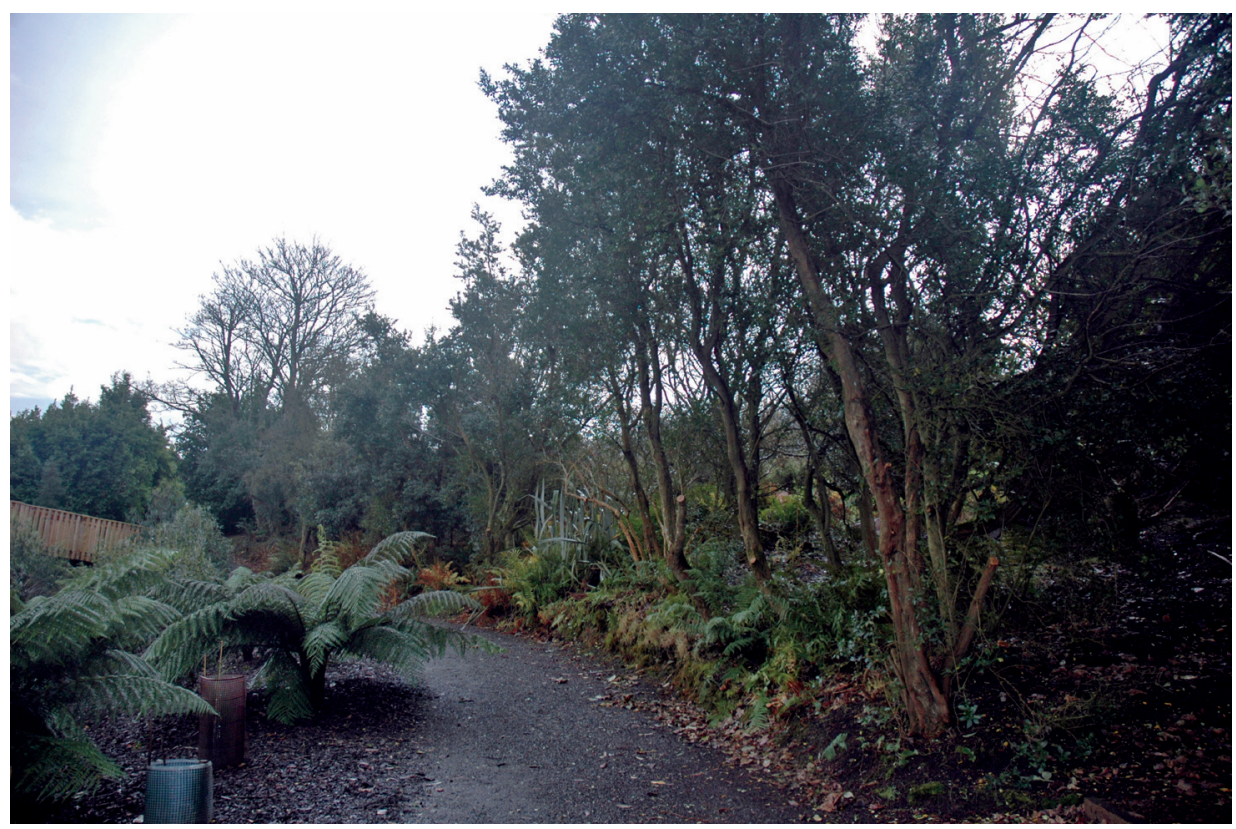

Fig. 3 Planting site, Location 3, of Blechnum cycadifolium at Logan Botanic Garden in south west Scotland. Photo: Colin Belton.

During the summer we do provide them with additional water in prolonged periods of drought and this will especially be the case this coming year to help with their establishment in their new location.'

The description of these conditions has some similarities with those experienced on Juan Fernandez and it is hoped that the plants will thrive in these exposed and windy but not cold conditions (Fig. 3).

\section{HOW THE PLANTS OVERWINTERED IN THESE LOCATIONS}

- The South American area. Only one plant out of the five that were planted survived the winter of 2005/06. It is thought that the accumulation of cold air and lack of winter sun in the area contributed to their deaths. It is also speculated that had the plants been larger and more mature they may have withstood the cold better. The plant which survived was planted closest to other larger shrubs in the bed and it would appear that these plants have afforded it some protection. The bed is sloped very slightly and the surviving plant is planted at the top of this. The plant appeared healthy through the winter of 2006/07, thus it seems that the corex case has improved its condition and potential to survive through the winter months (Fig. 4).

- The Courtyard. All of the plants here survived the winter well and are growing strongly. 
- Logan Botanic Garden. All but two of the 15 plants survived and are still growing well. The cause of death for those two is not thought to be related to low temperatures.

\section{CONCLUSIONS}

This species seems to tolerate temperatures down to $-5^{\circ} \mathrm{C}$ with little or no damage. However, low temperatures, lack of winter sunshine and areas where cold air accumulates, lead to reduced chances of survival.

Based on the prevailing conditions in their native environment, it is thought that they would survive better on a sloping, well-drained site in full sun, with an open aspect. These conditions can be found at another planting site at Logan where approximately 20 plants will be planted in summer 2007 .

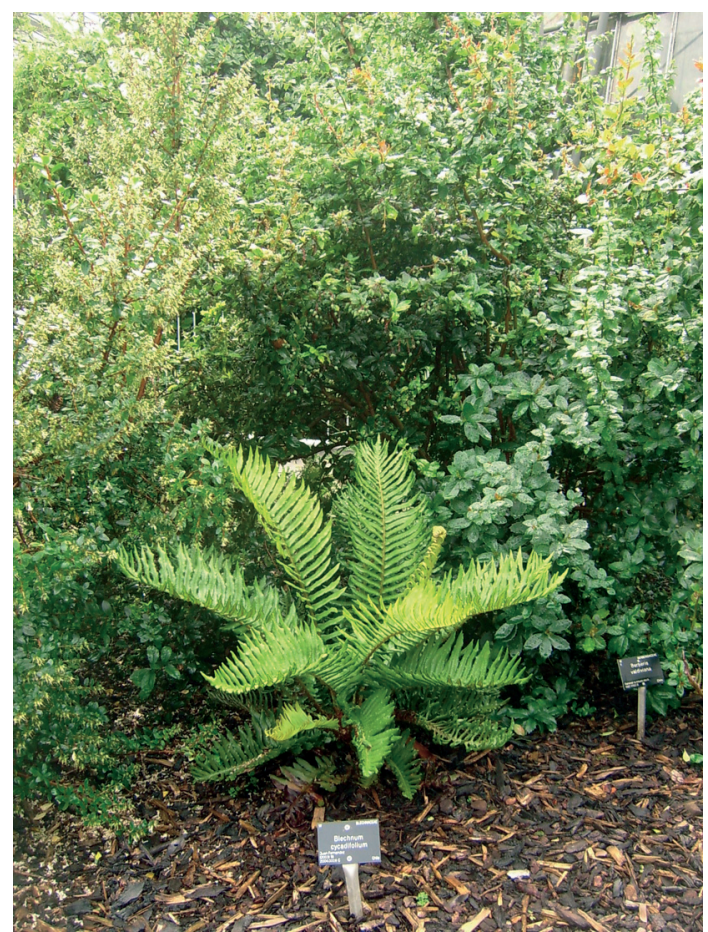

Fig. 4 Blechnum cycadifolium protected by surrounding shrubs in T27 RBGE Inverleith, in early summer 2007. Photo: Sadie Barber.

\section{REFERENCES}

WARDLAW, A. 2005. Tree fern apical temperatures at the Royal Botanic Garden Edinburgh. Sibbaldia: An occasional series of horticultural notes from the Royal Botanic Garden Edinburgh. 3, 17-26.

HABERLE, S. (1999). Human Impact on the Juan Fernandez Islands, Chile. http://arts.monash. edu.au/ges/who/haberle/JFernandez/JFernandez.html Accessed February 2007.

ENSOLL, A. AND MATTHEWS, K. (2004) Cultivation of Thyrsopteris elegans. Sibbaldia: An occasional series of horticultural notes from the Royal Botanic Garden Edinburgh. 3, 17-26. 